\title{
KEY DIFFERENCES IN APPROACHING EDUCATION IN KINDERGARTENAND PRIMARY SCHOOL
}

The difficulties in adjustment during the transition from kindergarten to school can be caused by different approaches in education used in these institutions. Different approaches used in the educational process in kindergarten and primary school can cause unnatural distance between these institutions, although it is absolutely expected that the best possible educational effects can be achieved only with their mutual effort. Apart from parents, preschool and school teachers represent the most important factor from social surrounding which influences the development of children systematically by means of implementation of different forms of learning. In this paper, we examined the estimates of preschool and school teachers, as experts who systematically influence child development and learning, about the differences in approaching education in kindergarten and primary school. The total sample of the examinees was comprised of 94 preschool teaches and 150 school teachers. For statistical processing of the data and determining statistical significance between the differences in the estimates made by preschool and school teachers, a nonparametric technique, Mann-Whitney $U$ test, was used. The result was statistically significant disparity in the evaluations by preschool and school teachers on the issue, which points to further important pedagogical implications. As one possible reason for significantly different estimates, we can suggest still present "poverty" of the partner relationships and relations between kindergarten and primary school, that is between preschool teachers and teachers. Based on the determined estimates of the examinees in our research, all future research should be oriented toward finding the most beneficial ways for connecting educational activities of kindergarten and primary school.

Keywords: preschool education, primary education, preschool and school teachers.

Introduction. Preschool and school education is closely related as they represent different parts of the system of life learning and their complementary relationship is expressed in many ways. The first dimension of their mutual relation stems from publicly proclaimed functions of preschool and elementary school education which permeate and complement each other. One of these functions of preschool education is preparing children for school, whereas elementary school education represents continuation of the initiated preschool education. The second important dimension of their correlation stems from the natural characteristics of preschool and younger school-age children. Namely, both groups of children require learning environment that will make them feel safe and which is similar to work and life conditions of their families. However, despite these facts, many authors point out that the transition from family or kindergarten to primary school, which is one of the most important events in the life of children, can present itself as difficult and unpleasant at the same time $[5,6,10,13]$. This is the reason why the transition from kindergarten to primary school is one of the current problems in pedagogy.

Preschool period and early experiences of children acquired in family and institutions for preschool learning are very important for the further development and success of the child $[4,11]$. In the sensitive period of the transition from kindergarten to primary school, the role of parents cannot be denied since they influence the formation of later relationship that children will have toward school [12]. Another important influence is the cooperation between teachers and parents even before the institutional education of preschool children [14]. When the contribution of educational institution is concerned, the results of one study showed that institutional early learning prior to the fifth year of age proved significant for achieving better results in the tests of intellectual development until age seven and even later, until age 16, although the influence by then is smaller [4]. Considering the nature of the correlation between preschool and elementary school education, we believe that one important practical task for the educational system is to create more solid partner relationships between educational institutions at the initial stages of child development.

Many studies worldwide have confirmed that there are differences in approaching education in kindergarten and primary school. Some authors point out that there are different approaches to education in the early childhood in some countries [2]. According to a research conducted in Estonia, preschool teachers and school teachers specified that there are certain similarities in their approaches, as well as differences [15]. This is why some authors conclude that it is necessary to create continuity in the formation of goals and curricula for the kindergartens and elementary schools, and provide better correlation between these institutions which are today unnaturally remote one from another [19].

Apart from parents, preschool and school teachers represent the most important factor from social surrounding which influences the development of children systematically by means of implementation of different forms of learning. In accordance to the nature of holistic program that is being realized in the kindergartens around Republika Srpska, as a constitutional part of Bosnia and Herzegovina, preschool teachers have the opportunity to set a more flexible learning framework that would take into consideration the individual differences among the children, the particularities of the educational group and children's age, as well as the particularities of the kindergarten surroundings. Unlike them, school teachers in our country are obliged to operationalize the prescribed curriculum without any opportunity to change it or digress from it in the situations when individual differences among children demand such action. The goal of the preschool curriculum that is being realized in the kindergartens around our country is to shape children's personality in all aspects [21], while in younger classes in elementary school, apart from the general development of the child, the focus is on achieving the concrete goals and outcomes of learning [18]. One of the main differences between kindergarten and primary school is the matter of estimating children's accomplishments. In kindergartens, grading is not used at all; however, in primary schools, it takes the form of description in the first class and the form of numeric grading from the second class on. Taking into account the characteristics of preschool age, kindergarten children are not expected to conform to strict discipline, while school children have to conform to strict discipline rules from the very beginning despite the fact that there is a very slight difference in the developmental characteristics of preschool and younger school children. Emotional climate in the preschool group and the relationship between preschool teachers and children are all based on spontaneous and free communication, while in school the roles of students and teachers are clearly differentiated. Teachers in kindergartens are oriented toward creating a pleasant climate for children in this institution, while school teachers are expected to prioritise and realise the 
curriculum with the contents that children are bound to acquire. Other characteristics present in education of children in kindergarten and primary school are determined by standards for formation of educational groups and classes. Considering particularities of the preschool age, educational groups in kindergarten are smaller in number, while classes in primary school number more children. If we observe the kindergarten and primary school from the architectural aspect, we can notice that kindergartens are usually smaller buildings, while school buildings are usually bigger.

Important questions that arise in relation to the matter of different approaches to education in kindergarten and primary school are: what are the direct and indirect consequences of such condition in the educational practice; who can make them plain and interpret them successfully; how do preschool and school teachers as agents in educational process perceive the mentioned characteristics, and so on. These and similar questions are unduly neglected in the educational system of our country although they provide an area for scientific research which is also the reason why this paper is dedicated precisely to them.

METHODS: Aims of research. Different approaches used in the educational process in kindergarten and primary school can cause unnatural distance between these institutions, although it is absolutely expected that the best possible educational effects can be achieved only with their mutual effort. Because of many and obvious differences between kindergarten and primary school, which have been described in many studies worldwide, we have decided to conduct an empirical research about this problem on the sample comprised of preschool teachers and teachers involved in the learning process of preschool children and children of younger school age. The goal of the research was to determine the estimates of these professionals about the extent to which differences in education in kindergarten and primary school can lead to discontinuity in the education of preschool children and children of younger school age. The subject of the research was estimates of preschool and school teachers about the differences in approaching education in preschool and primary school institutions. The specific goal of the research was to determine if there are any statistically significant differences in the estimates of preschool teachers and teachers about the differences in approaching education in kindergarten and primary school. Our initial expectation, and at the same time the general hypothesis of the research, was that there are statistically significant differences in the estimates of preschool teachers and teachers and the extent to which the differences in approaching education in kindergarten and primary school can lead to discontinuity in the education of preschool children and children of younger school age.

Variables and research instruments. Beside the method of theoretical analysis and synthesis, the descriptive method was also used as well as the techniques of survey and survey questionnaire that served as the instrument for gathering data. The examinees took part in the research voluntarily and were explained that the gathered data will be used only for the scientific purposes. Therefore, none of the problems were recorded during the implementation of the research. The survey questionnaire was comprised of the inventory for gathering basic data about the examinees: professional role, years of age, years of service, and estimate scalar. The estimate scalar "VOS", adjusted for the purposes of this research from earlier Kakavulis's research [16], consisted of 13 differences between kindergarten and primary school. Next to every given difference on the fourthlevel scale $(0,1,2,3)$, the examinees were expected to provide estimates to what extent the given difference leads to discontinuity in the education of preschool children and children of younger school age. For this purpose, 0 signified the lowest contribution, while 3 the greatest contribution. During the verification of the metrical characteristics, the scalar showed excellent reliability which was determined by calculation of Cronbach's Alpha coefficient which numbered, 934.

Independent variable in the research was represented by professional roles that the examinees have in their educational practice: the role of the preschool teacher in kindergarten and the role of the teacher in primary school. Dependent variable was represented by their estimates about the differences in approaching education in kindergarten and primary school.

The sample and research procedure. The basic group, that is the population we used to choose the sample units from, consisted of all preschool teachers employed in the private and state kindergartens in the eastern part of Republika Srpska and Brcko District, as well as all teachers employed in primary schools who worked with students of younger school age (the first and the second grade) in the year when the research was conducted. The research sample was representative in relation to the population in eastern part of Republika Srpska, including the towns of Zvornik, Bijeljina and Brcko District (and the town of Doboj when teachers of younger school age children are concerned). The research was realized by the author of this paper in the period between January and April 2016.

Techniques used for statistic analysis of the data. The analysis of the data gathered in this empirical research was conducted by means of statistical program SPSS 20.0. For statistical processing of the data and determining statistical significance between the differences in the estimates made by preschool and school teachers, a nonparametric technique, Mann-Whitney $U$ test, was used.

Results. Starting from the primary goal of the research, which was to find out if preschool and school teachers differ in their estimates about the differences in approaching education in kindergarten and elementary school, the results of this research are showed according to the data received by Mann-Whitney $U$ test.

From the data showed in Table 1, it can be seen that value $Z(-2,23)$ is rounded, with the level of significance being $(p=0,026)$, where $p<0,05$, which is why this result can be considered as statistically significant. In other words, the result shows that there is statistically significant difference between estimates of preschool and school teachers about the differences in approaching education in kindergarten and elementary school.

Table 2 reveals the direction of the determined difference between the two groups of examinees: preschool teachers and school teachers. Based on the given data, we can see that the continuous variable is on average greater in the group of preschool teachers.

The evaluations by preschool and elementary school teachers about the differences in approaching education in kindergarten and elementary school (Test Statistics)

\begin{tabular}{|c|c|}
\hline \multicolumn{2}{|c|}{ education in kindergarten and elementary school (Test Statistics) } \\
\hline Mann-Whitney U & 5853,500 \\
\hline Wilcoxon W & 17178,500 \\
\hline Z & $-2,232$ \\
\hline Asymp. Sig. (2-tailed) & 0,026 \\
\hline
\end{tabular}


The evaluations by preschool and elementary school teachers about the differences

Table 2 in approaching education in kindergarten and elementary school (Ranks)

\begin{tabular}{|c|c|c|c|}
\hline Examinee & N & Mean Rank & Sum of Ranks \\
\hline School teachers & 150 & 114,52 & 17178,50 \\
\hline Preschool teachers & 94 & 135,23 & 12711,50 \\
\hline Total & 244 & & \\
\hline
\end{tabular}

Source: Own

The evaluations by preschool and elementary school teachers about the differences

Table 3 in approaching education in kindergarten and elementary school (Report)

\begin{tabular}{|c|c|c|}
\hline Examinee & $\mathbf{N}$ & Md \\
\hline School teachers & 150 & 50,00 \\
\hline Preschool teachers & 94 & 52,00 \\
\hline
\end{tabular}

Table 3 provides the data on the medians of the two groups of the examinees. Here, we can also notice that greater value of the median is recorded among the preschool teachers. Mann-Whitney $U$ test revealed a significant difference between teachers and preschool teachers concerning their estimates about the education in kindergarten and primary school, which can be considered as small influence according to Cohen's criterion [3]. Based on the given results, it can be concluded that our initial hypothesis - that there are statistically significant differences in the estimates of preschool and school teachers about the measure to which differences in approaching education in the kindergarten and primary school can lead to discontinuity in the education of children of preschool and younger school age - has been confirmed.

Discussion. The results of our research show that preschool teachers and teachers significantly differ in their estimates in approaching education in kindergarten and primary school. Statistical indicators also show that the determined difference is small, but this data is worrying if we take into consideration the scope of the examined sample and territorial prevalence of the teaching staff in the kindergartens and primary schools in Republika Srpska as a constitutional part of Bosnia and Herzegovina.

The importance of continuity in learning and development as a process is pointed out many times in pedagogical literature [20], just like the continuity between family, kindergarten and primary school as institutions [5], or between parents, preschool teachers and teachers as the most important factors from the social environment of the child that influence his/her education [13]. From this reason, it would be desirable to have uniform estimates of preschool teachers and teachers who are the closest partners to parents on the road to child development and education. However, if they give different estimates on the same issue then there is a real danger that, in practice, an individual child is not perceived at all and that "acting on the group" is more preferable which serves as the empirical evidence on the disagreement between working concepts in kindergartens and primary schools. Furthermore, the data about the statistically significant differences between median estimates of preschool teachers and teachers points to the danger that in the close future these professionals will not be able to establish functional relationships and continuity in their educational work. The preschool system and primary school system should be integrated and if not, it can undoubtedly cause irreparable damage to the development of future generations of children.

As one possible reason for significantly different estimates, we can suggest still present "poverty" of the partner relationships and relations between kindergarten and primary school, that is between preschool teachers and teachers. Here, there is also the question of presence of different concepts in the educational practice related to working with children since some kind of "obligation and compelling" in the learning process is still predominate in primary schools, while the work in kindergarten is based on encouraging children to accomplish what is discreetly offered to them as an activity, or what they choose by themselves. During the transition from kindergarten to primary school, it is obvious that "similarities" in working methods should be much more preferable to differences among them. Children can successfully start primary school only if it provides them with natural continuation of interactive relationships, close to the experiences they had in kindergarten. This would considerably relieve the transition of the six-year-olds to primary school.

Contemporary theoretical sources offer a range of potential measures and solutions which could influence the connection and single educational functioning of kindergarten and primary school. Some of these are: common education of preschool teachers and teachers about the questions related to both of the groups, joint activities of these groups aimed at the realization of educational tasks, and so on [17]. Other scholars recognize the need for introducing different forms of professional training for preschool teachers in order to improve their knowledge and the development of new skills [11]. Some authors share the opinion that curricula should include acquiring of theoretical and practical knowledge related to game-based learning [8]. This would affirm and mark the game not just as an activity inherent to preschool age, but the activity with rich potential that can also be used in the education of the children of younger school age. One Finnish study examined the attitudes of teachers working in primary schools about the possibilities of implementing the game in school work and learning. According to these results, teachers thought that game could be integrated in every school subject. The examinees stated that different subject matter could be integrated through game in the following fields: music, history, mathematics, native language and so on [8]. Other studies denoted game as the leading activity in entire childhood with a very special place in the school learning process [1]. Types of games suitable for school learning are: imagination games, construction games, creative games, language and memory games etc. [1]. Some authors suggest creation of common curriculum in the early childhood as one of the measures that could secure single educational functioning of kindergarten and primary school and provide opportunity for parents and preschool teachers to learn from each other about the children themselves [7]. Others conclude that: "All agents in educational and learning process should take responsibility for its ultimate outcome which can be reached only by dialogue and joint, partner efforts - this outcome being fully integrated, educated and accomplished personality, with the corresponding set of values, attitudes and beliefs ..., who learns for life (and not for school)" [9, p. 11-12]. 
Based on the determined estimates of the examinees in our research, all future research should be oriented toward finding the most beneficial ways for connecting educational activities of kindergarten and primary school. This could also mean verification of practical applicability and efficiency of measures and solutions referred to in the literature.

Conclusions. Based on theoretical study of the given issue, as well as the results of our empirical research, the following conclusions and important pedagogical implications can be enlisted:

- preschool and primary school education are inseparable parts of the system of life learning and the first, basic, levels of education on the road to child development and adulthood;

- one of the problems children have during the transition from preschool to younger school age are different approaches to education implemented in kindergarten and primary school. As opposed to the actual state in educational practice, children of preschool and younger school age call for far more similarities in educational methods than differences among them. This is why contemporary theoretical sources on learning in younger school age tend to level their methods to those used in early learning;

- basic differences between approaching education in kindergarten and primary school, which are stated in literature, revolve around: different program orientations, teaching goals realised in these institutions, discipline and evaluation of children accomplishments, the number of children in kindergarten groups and school classes, the appearance of kindergarten and school, emotional climate and relationships between children and preschool teachers, as well as children and teachers etc.;

- a representative sample of preschool and school teachers showed that there are statistically significant differences between the estimates of preschool and school teachers about approaches to education in kindergarten and primary school. In our research, preschool teachers estimated that there are differences in approaching education in kindergarten and primary school in significantly greater measure than teachers; they also proposed that these differences lead to discontinuity in the education of children and cause widening of the gap between preschool and primary school education. Discontinuity in educational work of these institutions can cause difficulties in children's adjustment to primary school;

- this data points to the necessity of changing the attitude toward educational work of preschool and school teachers by the creators of educational policy and wider public and also of creating the educational policy that would influence the connection between kindergarten and primary school for the better in order to provide maximum support to children and their development;

- if preschool teachers and teachers, as professionals who systematically influence the development and education of children of preschool and younger school age, could together, without any mutual grievances, evaluate what the biggest differences in approaching education in the kindergarten and primary school are, this would clearly point to the direction of necessary action in order to neutralise these differences and better connect the work of these institutions for the benefit of the children;

- preschool teachers employed in kindergartens and teachers employed in primary schools need some kind of common education and professional training that could lead to functional bonding of their common educational activities. This need derives from the fact that preschool children and the children of younger school age are in need for implementation of similar work concepts and educational process with respect to the nature of learning most suitable to them;

- professional staff, preschool and school teachers, could even during their college education be introduced to the importance of maintaining continuity in the educational process in kindergarten and primary school, and thus be better prepared to use the acquired knowledge and skills in practice. This way, the transition from preschool childhood to the younger school age could be less painful and awkward experience for children as is usually denoted in the literature;

- based on the results of this research, it is possible to start a new research, on the second and bigger sample of the examinees, and also use the gathered results for writing the strategy for the development of education in our country, in the part that speaks about professional training of the people employed in kindergartens and primary schools.

\section{References}

1. Carr J. Approaches to Teaching \& Learning. INTO Consultative Conference on Education. [Electronic resource] / J. Carr, C.M. Éireann, B. A. Cliath, Á. Rúnaí. - 2007. https://www.into.ie/ROI/Publications/Approaches TeachingandLearning.pdf. - Accessed on 17th Jan. 2018

2. Chartier A. Pedagogical approaches to early childhood education. [Electronic resource] / A. Chartier, N. Geneix // Paper commissioned for the EFA GlobalMonitoring Report 2007, Strong foundations: early childhood care and education. https://unesdoc.unesco.org/ark:/48223/pf0000147448_eng. Accessed on 17th Jan., 2018.

3. Cohen J. Statistical power analysis for the behavioral sciences (2nd ed.) / J. Cohen. - NJ : Lawrence Earlbaum Associates, 1988

4. Goodman A. Early education and Children's outcomes: How long do the impacts last? [Electronic resource] / A. Goodman, B. Sianesi // Fiscal Studies, 2005. - No. 26 (4). - P. 513-548. URL: https://onlinelibrary.wiley.com/ doi/abs/10.1111/j.1475-5890.2005.00022.x. - Accessed on 11th Jan., 2018.

5 . Greubel S. The developmental and social ramifications of the transition from kindergarten to primary school. [Electronic resource] / S. Greubel // Research on Steiner Education, 2014. - No. 2. - P. 130-140. URL: http://www.rosejourn.com/index.php/rose/article/view/229. - Accessed on 12th Jun., 2018

6. Hirst M. Transition to primary school: A review of literatury. [Electronic resource] / M. Hirst, N. Jervis, K. Visagie et al., 2011. URL: https://www.kidsmatter.edu.au/sites/default/files/public/Transition-to-

Primary-School-A-literature-review.pdf. - Accessed on 12th Aug., 2013

7. Hyde A. What are the Important Elements of the Pre-Primary Curriculum?: The Views of Parents and Teachers. [Electronic resource] / A. Hyde, 1999. URL: https://ro.ecu.edu.au/theses hons/753. - Accessed on 23th Jun., 2014

8. Hyvonen P.T. Play in the School Context? The Perspectives of Finnish Teachers. [Electronic resource] / P.T. Hyvonen // Australian Journal of Teacher Education, 2011. - No. 36 (8). URL: https://ro.ecu.edu.au/cgi/viewcontent.cgi?article=1645\&context=ajte. Accessed on 11th Jan., 2018.

9. Jukić R. Roditelji kao sukonstruktori suvremenog kurikuluma / R. Jukić // Zbornik sažetaka plenarnih izlaganja i priopćenja Partnerstvo u odgoju i obrazovanju, Filozofski fakultet Osijek, 2015, - P. 11-12.

10. Lee S. Action Research to Address the Transition from Kindergarten to Primary School: Children's Authentic Learning, Construction Play, and Pretend Play. [Electronic resource] / S. Lee, G. Goh // Early childhood research and practice, 2012. - No. 1. URL: http://ecrp.uiuc.edu/v14n1/lee.html. - Accessed on 23th Jun., 2014.

11. McCrea L. Kindergarten Teachers' Perceptions of and Expectations for School Readiness: Self-Regulation and Success / L. McCrea // PCOM Psychology Dissertations, 2013. - P. $355 . \quad$ URL: https://digitalcommons.pcom.edu/cgi/viewcontent.cgi?article=1354\&context= psychology_dissertations. - Accessed on 17th Jan., 2018.

12. Reichmann $\mathrm{E}$. The transition from German kindergarten to primary school: parents' role in the transition process / E. Reichmann // Internat. Jour. of Transitions in Childhood, 2011/2012 - Vol. 5 - P. 22-32. URL: https://extranet.education.unimelb.edu.au/LED/tec/pdf/journal5_reichmann.p df. - Accessed on 30th July, 2018.

13. Rosier K. Promoting positive education and care transitions for children. [Electronic resource] / K. Rosier, M. McDonald // CAFCA Resource Sheet, 2011. URL: https://aifs.gov.au/cfca/publications/promoting-positiveeducation-and-care-transitions-children. - Accessed on 19th July, 2015.

14. Spasojevic P. Collaboration of parents and institutions in support of proper development of preschoolers / P. Spasojevic, M. Samardzic, M. Travar // Open education as a way to a knowledge society, 12th conf. reader, 2017. P. 442-458

15. Uibu K. Instructional Approaches: Differences between Kindergarten and Primary School Teachers. [Electronic resource] / K. Uibu, E. Kikas, K. Tropp // Compare: A Journal of Comparative and International Education, 
2011. - Vol. 41. - No. 1. - P. 91-111. https://eric.ed.gov/?id=EJ907440. Accessed on 29th July, 2017.

16. Какавулис А. Континуитет у васпитању у раном дјетињству: прелазак из предшколске установе у школу / А. Какавулис // Настава и васпитање часопис за педагошку теорију и праксу, 1998. - Р. 78-90.

17. Копас-Вукашиновић Е. Васпитни рад у дечјем вртићу и школи остваривање континуитета у избору и реализацији задатака / E. КопасВукашиновић // Нова школа, 2010. - Р. 176-185.

18. Наставни план и програм за основно образовање и васпитање / Источно Сарајево: Завод за уџбенике и наставна средства, 2014.
19. Спасојевић П. Игра и рано учење / П. Спасојевић - Српско Сарајево: Завод за уџбенике и наставна средства, 2003

20. Спасојевић П. Основна школа између традиције и реформе у контексту успостављања и очувања континуитета учења и развоја / П. Спасојевић // Зборник радова са научног скупа Будућа школа, Српска академија образовања, 2009. - Р. 476-494.

21. Програм предшколског васпитања и образовања / П. Спасојевић Т. Прибишев Белеслин, С. Николић // Источно Сарајево: Завод за уџбенике и наставна средства, 2007.

Надійшла до редколегії 12.02.19

М. Травар, канд. пед. наук, асист.

Університет Східного Сараєво, Сараєво, Боснія та Гецоговина

\section{КЛЮЧОВІ РІЗНИЦІ В ПІДХОДІ ДО ОСВІТИ В ДИТЯЧОМУ САДКУ ТА ПОЧАТКОВІЙ ШКОЛІ}

Труднощі в адаптації під час переходу від дитячого садка до школи можуть бути викликані різними підходами в освіті, що використовуються в цих закладах. Різні підходи в освітньому процесі в дитячому садку та початковій школі можуть викликати неприродну відстань між цими установами, хоча абсолютно очікується, що найкращі можливі освітні ефекти можуть бути досяенуті лише за їхніх спільних зусиль. Окрім батьків, дошкільні та шкільні вчителі є найважливішим фактором із соціального оточення, який систематично впливає на розвиток дітей шляхом реалізації різних форм навчання. Розглянуто оцінки вчителів дошкільного та шкільного віку як експертів, які систематично впливають на розвиток та навчання дитини, на відмінності у наближенні до освіти в дитячому садку та початковій школі. Загальна вибірка опитаних становила 94 дошкільних вчителів та 150 шкільних вчителів. Для статистичної обробки даних і визначення статистичної значущості між відмінностями в оцінках, проведених дошкільними та шкільними вчителями, використано непараметричну методику, U-тест Манна-Уітні. Результатом стала статистично значна невідповідність оцінок у дошкільних і шкільних вчителів із цього питання, що вказує на подальші важливі педагогічні наслідки. Як одну з можливих причин для істотно різних оцінок можна припустити відсутність партнерських відносин між дитячим садом і початковою школою, тобто між вчителями та вчителями дошкільного віку. Виходячи з визначених оцінок досліджуваних у нашому дослідженні, усі подальші дослідження мають бути орієнтовані на пошук найбільш вигідних шляхів для підключення навчальної діяльності дитячого садка та початкової школи.

Ключові слова: дошкільна освіта, початкова освіта, дошкільні та шкільні вчителі.

M. Zhylenko, Ph. D. (Pedagogical Sci.), Assoc. Prof. Taras Shevchenko National University of Kyiv, Kyiv, Ukraine

\section{PRACTICAL TRAINING OF PROFESSIONALS IN THE HIGHER EDUCATION SYSTEM OF INDEPENDENT UKRAINE}

The paper analyzes approaches to practical training organization in Ukrainian system of higher education in the period - the end of the 20th - beginning of the 21st century. Particular emphasis is placed on modern requirements. Exclusive attention is paid to the analysis of the modern educational paradigm. The process of changing the requirements for practical training in accordance with the transformational processes taking place in the system of higher education in Ukraine is considered in detail. Tasks of practical training are considered in the framework of modernization of educational and professional standards, requirements of the legislative and regulatory framework, creation of conditions for the involvement in the processes of building a new innovative National Qualifications System (NQS). Practical training is considered through the normative content of the training of higher education graduates, formulated in terms of programmatic learning outcomes and correlated with a specific list of general and special (professional, subject) competencies. Tasks for practical training of students are considered as a component of the whole educational program, which should be integrated into its philosophy and content and ensured by the procedure for determining the place of practical training in the matrices of matching competencies and program learning outcomes.

Keywords: practical training, educational standard, higher education standard, educational program, general competencies, professional competencies of the specialty, program learning outcomes.

Formulation of the problem. The Law of Ukraine "About Higher Education" (Articles 50, 51) defines practical training as one of organization forms of educational process, which is done over undertaking an internship on enterprises, institutions and organizations in accordance with the contracts of higher education institutions or in its structural units providing practical training [3]. According to the theory of knowledge, practice should complete this process. That is why until recently, practical training was planned as the final stage of educational activity in higher education institutions. But the problem is not in determining its place in the educational process, but more in the direction, content, tasks that need to be addressed in the process of practical training. Those statements determine the relevance of this work.

In the second half of the twentieth century, the world community entered a new phase in its development - postindustrial, accompanied by changes in the temporal scale of socio-historical progress. The world is changing fast. Political, economic and social relations are constantly transforming significantly increases the pace of people's life. The complication of activity has place. Changes become permanent.
In particular these circumstances are relevant to modern research activities, especially in educational sphere, during which the formation of a specialist and personality for modern society should take place.

Studying the role of classical universities in the modern educational system [1], we came to conclusion that the transition to technological society, structured on the principles of communicative and professional relations within the designtechnological type of organizational culture, will require the training of specialists capable of creating projects that will be successful in a competitive environments with the development of the project-technological type of organizational culture, projects and programs become large scale and require specialists capable of servicing them. It should be provided with the ability to conduct analytical work, requires a level of transformation of theoretical knowledge, a productive approach to their use.

The purpose of the work is to find out to what extent the legislative, normative and methodological basis for organizing the educational process can provide practical training of graduates to productive activities on a reflexive basis. To achieve this, 